\title{
Development of Mytilus edulis embryos: a bioassay for polluted waters
}

\author{
D. Johnson \\ Water Research Centre, Environment Laboratory, Medmenham, Marlow, Buckinghamshire SL7 2HD, United Kingdom
}

\begin{abstract}
In the course of the GEEP Workshop, water from 4 mesocosm basins dosed with differing levels of a diesel oil and $\mathrm{Cu}$ mixture was subjected to an embryo development bioassay using Mytilus edulis. The method used for the bioassay was based on the standard ASTM method but modified to suit local equipment availability since the bioassay was not originally planned in the workshop programme. The end point of the bioassay was the development to D-stage which was achieved in the control mesocosm water after $72 \mathrm{~h}$. Significant $(p=0.05)$ effects were detected in the highest dose water. Net. Treatment Mortality in the medium-dose mesocosm $\left(5 \mu \mathrm{g} \mathrm{l}^{-1}\right.$ copper and $28.5 \mu \mathrm{g} \mathrm{l}^{-1}$ petroleum hydrocarbons) was $50 \%$; this corresponds well with a reported $\mathrm{EC}_{50}$ for mussel embryo in copper at $5.8 \mu \mathrm{g} \mathrm{Cu}$ $1^{-1}$
\end{abstract}

\section{INTRODUCTION}

Marine mussels of the genus Mytilus have a number of characteristics which make them suitable as a test organism for environmental monitoring. They have a widespread distribution globally, are found in both coastal and estuarine waters, and are important both economically and ecologically. The physiology of adults has been well documented (e.g. Bayne 1976) and this extensive understanding has encouraged the use of the adult for the detection and monitoring of pollution effects in coastal waters (Goldberg et al. 1978). The genetics and embryology of Mytilus edulis is also well documented (Bayne 1976) making available some more sophisticated techniques for monitoring. The free-living larval stage has been found to be particularly sensitive to a wide range of pollutants and its use for routine toxicity testing was first proposed by Dimick \& Breese (1965). Since then the technique has been adapted for both toxicity testing and field monitoring (Armstrong \& Millemann 1974, ASTM 1980, Martin et al. 1981, Beaumont \& Budd 1984).

The technique involves separate collection of male and female gametes from ripe adults and fertilisation under controlled conditions, to produce embryos in the early stages of development. These are then added to test waters which may be water samples taken directly from the environment, dilutions of effluent, extracts from sludge, dredged spoil or sediments, or in the case of toxicity testing, dilutions of the test compound. Embryos are then incubated at constant temperature for a given period of time and the number of embryos developing to the easily identifiable D-stage of Prodissoconch-I stage counted. The success rate of development is then compared with the development in control water, which may be a standard clean sea water or some other reference water taken from a known uncontaminated area.

The use of Mytilus species has followed the development of an identical bioassay using oysters. Both assays meet several criteria recommended by Stebbing et al. (1980) for marine bioassays used in pollution monitoring. They are (1) cost effective; (2) do not require expensive equipment; (3) are short term, taking hours or days rather than weeks for completion. For a bioassay to be of maximum use it is advantageous to be able to carry out the assay at all times of the year and not to be restricted to those times when gametes are available by virtue of the seasonal spawning pattern of natural populations. It has been demonstrated that it is possible to manipulate both oysters and mussels in such a way as to have ripe adults available at most times of the year. Bayne (1965) and Dixon \& Prosser (1986) were able to keep ripe adult mussels in a spawning condition for periods up to 6 mo after their normal spawning time in recirculating seawater at 4 to $5^{\circ} \mathrm{C}$, while maintaining them on an algal diet. After this time, induction of spawning became more difficult. Mussels which have already begun to accumulate glycogen reserves can be encouraged to accelerate gametogenesis. Bayne (1965) and Mitchell et al. (1985) achieved this by raising the water temperature and 
providing a suitable algal diet. This widens the applicability of the technique to an almost year-round bioassay

The bioassay described here was not part of the original programme for the GEEP Workshop. It was very much an opportunistic bioassay facilitated by an abundant supply of ripe mussels in one of the mesocosm basins which could be induced to spawn with little preparation. The fact that it was possible to carry out the bioassay at such short notice, with simple laboratory equipment, and that it proved possible to demonstrate an effect consistent with the level of pollutants in the water, underlines the value of the technique for measurements of water quality.

\section{MATERIAL AND METHODS}

The bioassay was carried out on water collected from the 4 mesocosm basins in twelve $100 \mathrm{ml}$ glass bottles numbered 1 to 12 . Numbers were randomly allocated to bottles and the correspondence was not made known until the bioassay had been completed. This was therefore a fully 'blind' trial, in that the experimenter did not even have knowledge of which bottles were replicates from the same (unknown) treatment.

Three mesocosm basins were dosed with a mixture of $\mathrm{Cu}$ and diesel oil, at the following water concentrations (nominal values for $\mathrm{Cu}$ and fluorescence spectrometry measurements for hydrocarbons, Bakke et al. 1988). Low dose: $0.8 \mu \mathrm{g} \mathrm{l}^{-1} \mathrm{Cu}$ and $6.4 \mu \mathrm{g} \mathrm{l}^{-1}$ hydrocarbons; medium dose: $5 \mu \mathrm{g} \mathrm{l}^{-1} \mathrm{Cu}$ and $31.5 \mu \mathrm{g} \mathrm{l}^{-1}$ hydrocarbons; high dose: $20 \mu \mathrm{g} \mathrm{l}^{-1} \mathrm{Cu}$ and $124.5 \mu \mathrm{g} \mathrm{l}^{-1}$ hydrocarbons; the 4 th mesocosm basin was not dosed and served as a control (measured hydrocarbon concentration $3 \mu \mathrm{g} \mathrm{l}^{-1}$ ).

Aduit Mytilus edulis were taken from the mediumdose mesocosm basin and cleaned of all attached growth to remove possible contaminants. They were placed in flowing water taken from Oslofjord to clear the mantle cavity of water from the dosed basin, prior to being placed in warmed (ca $25^{\circ} \mathrm{C}$ ) seawater for $10 \mathrm{~min}$, to induce spawning. Following warming, the mussels were placed in individual beakers of fjord water to allow male and female gametes to be collected separately. An egg suspension was made from 3 different females, and sperm were collected from 3 males and added to the eggs. Observations were made of the eggs at $15 \mathrm{~min}$ intervals to determine the progress of cell division. The first cleavage was seen 30 min after the mixing. After $2 \mathrm{~h}$, division was well advanced and at this point the dividing embryos were added to the numbered bottles to give a density of ca $20 \mathrm{ml}^{-1}$. Three additional bottles were inoculated and immediately preserved with formalin to allow enumeration of the inoculum.
There were no controlled temperature incubation facilities available so incubation was carried out in a static water bath at room temperature (ca $15^{\circ} \mathrm{C}$ ). Embryonic development was examined at regular intervals for $72 \mathrm{~h}$ following the addition of embryos to the test conditions. Development was arrested by the addition of formalin to the bottles. Development was assessed by counting the number of successfully developed D-stage larvae in single sub-samples of each bottle concentrated 10 -fold by sedimentation in simply calibrated test tubes. Counting was carried out using a conventional binocular compound microscope and a $1 \mathrm{ml}$ Sedgwick-Rafter counting chamber.

\section{RESULTS}

Table 1 gives the numbers of dividing eggs in samples taken from each of the 3 replicate bottles prepared for initial inoculum counts. Although the concentration of $26 \mathrm{ml}^{-1}$ is higher than the optimal number for the bioassay $\left(20 \mathrm{ml}^{-1}\right)$ it was not so high as to render the assay invalid.

Numbers both of embryos successfully developing to the ' $D$ ' stage and those not reaching that stage in each of the treatment replicates are shown in Table 2 ,

Table 1. Mytilus edulis. Numbers of dividing embryos in each of the 3 replicates for the initial inocula

\begin{tabular}{cc|}
\hline Replicate & Dividing embryos per $10 \mathrm{ml}$ \\
\hline a & 276 \\
b & 253 \\
c & 237 \\
\hline
\end{tabular}

Table 2. Mytilus edulis. Numbers of 'D-stage', non 'D-stage and total surviving larvae (per $10 \mathrm{ml}$ ) in 3 replicate bottles from the 4 mesocosm basins; C: control, L: low, M: medium, $\mathrm{H}$ : high-dose of a copper and diesel oil mixture. (Note that 1 replicate is missing for the $\mathrm{H}$ basin, through a failure to inoculate the bottle)

\begin{tabular}{|cccc|}
\hline \multirow{2}{*}{ Basin } & D-stage' & Non D-stage' & Total larvae \\
\hline \multirow{2}{*}{ C } & 12 & 88 & 100 \\
& 99 & 40 & 139 \\
& 99 & 84 & 183 \\
L & 36 & 93 & 129 \\
& 53 & 58 & 111 \\
& 80 & 58 & 138 \\
M & 32 & 161 & 193 \\
& 65 & 60 & 125 \\
& 7 & 80 & 87 \\
H & 0 & 11 & 11 \\
& 0 & 4 & 4 \\
\hline
\end{tabular}


together with the total number of surviving embryos irrespective of the stage of development. These total numbers are similar for control, low and medium dose samples, while there was a high level of mortality in high-dose samples.

Data for the number of embryos developing to the Dstage were square-root transformed and an analysis of variance carried out. This revealed a significant between-treatment difference $(p=0.05)$, the main difference being between the high dose and the control and low dose samples.

\section{DISCUSSION}

The conditions under which the bioassays were carried out were not consistent with those normally prevailing in a laboratory routinely conducting such tests, since most of the equipment had to be located at very short notice. However, it was possible to control the numbers of eggs and sperm in such a way as to give numbers of dividing embryos in the test waters which were not markedly different from those normally used. Here, the number was $26 \mathrm{ml}^{-1}$, the usual range of embryo density being 10 to $20 \mathrm{ml}^{-1}$ (Armstrong \& Millemann 1974, ASTM 1980, Mitchell et al. 1985).

Net treatment mortality (NTM) for D-larvae in each of the mesocosm waters can be calculated from the equation

$$
\text { NTM }=100\left[1-\left(N_{\mathrm{t}} / N_{\mathrm{c}}\right)\right]
$$

where $N_{\mathrm{t}}=$ number of surviving D-larvae in the treatment; $N_{\mathrm{c}}=$ number of surviving D-larvae in the control. This gives values for the low, medium and high-dose waters of 20,50 and 100 respectively. Martin et al. (1981) report a $48 \mathrm{~h} \mathrm{EC}_{50}$ for copper of $5.8 \mu \mathrm{g} \mathrm{l} \mathrm{l}^{-1}$. Clearly, the nominal copper concentration $\left(5.0 \mu \mathrm{g} \mathrm{l}^{-1}\right)$ in the medium dose basin water is of the correct magnitude to account fully for the observed $50 \%$ NTM.

The other major component of the dose to the mesocosms was the petroleum hydrocarbons. Published data on the effects of these on bivalve embryos is scarce; most of that which is available relate to crude oils and their water soluble fractions (WSF). The levels of hydrocarbons which give rise to significant effects are, in all cases, higher than those used in this experiment. In his review, Corner (1978) suggests that the levels of total hydrocarbons reported for the Sargasso Sea (559 $\mu \mathrm{g} \mathrm{l}^{-1}$ ), the North Sea $\left(625 \mu \mathrm{g} \mathrm{l}^{-1}\right.$ ) and Goteborg Harbour $\left(710 \mu \mathrm{g} \mathrm{l}^{-1}\right)$ are sufficiently high to affect larval development of bivalves.

Bryne \& Calder (1977) found that the effects of hydrocarbons on Mercenaria sp. were greatest during the first $48 \mathrm{~h}$ of development; the $48 \mathrm{~h} \mathrm{LC}_{50}$, however, varied between 230 and $12000 \mathrm{\mu g} \mathrm{l}^{-1}$ (total oil hydro- carbons in the WSF). This wide variation may be attributed to different proportions of lower molecular weight hydrocarbons in crude oil from different sources, or to the fact that nominal concentrations are quoted rather than measured concentrations. In some cases actual concentrations, particularly of the more toxlc oil components, may be as low as $5 \%$ of the nominal level. Bioassays on light crude oil using the oyster Crassostrea gigas were reported by Cormack (1983). In this case concentrations are as total added crude and not as the WSF concentrations. Interpolation of the data reveals a $24 \mathrm{~h} \mathrm{EC}_{50}$ of ca $875 \mu \mathrm{g} \mathrm{l^{-1 }}$.

Concentrations of hydrocarbons in the low, medium and high-dose mesocosm basins were measured by fluorescence spectrometry as $6.4,31.5$ and $124.5 \mu \mathrm{gl}^{-1}$ (Bakke et al. 1988), all lower than the values reported above. Cormack (1983) also gave measurements of total hydrocarbons in water samples for oyster bioassays taken from under an oil slick. The concentrations found ranged from 1 to $130 \mu \mathrm{g} \mathrm{l}^{-1}$, a range similar to that in the basins. Although Cormack reports significant reductions in embryo development, there was no evidence of a direct exposure/response relation between the measured hydrocarbon concentration and developmental failure. Taking these findings into account it is unlikely that any direct response by mussel embryos in the mesocosm waters would be observed. This conclusion should be tempered, however, by uncertainty regarding the true $\mathrm{EC}_{50}$ of aromatic hydrocarbons on mussel embryos.

Finally, in spite of the large within-treatment variability for the current (sub-optimal) bioassay, the pattern of response with regard to the development of D-stage larvae was similar to that shown by the physiological response of the adult mussels, as measured by scope for growth (Widdows \& Johnson 1988).

\section{LITERATURE CITED}

American Society for Testing and Materials (ASTM) (1980) Standard practice for conducting static acute toxicity tests with larvae of four species of bivalve mollusc. Annual Book of ASTM standards, E724-80

Armstrong, D. A., Millemann, R. E. (1974). Effects of the insecticide Seyin and its first hydrolytic product, 1-napthol, on some early development stages of Mytilus edulis. Mar Biol. 28: 11-15

Bakke, T., Follum, O. A., Moe, K. A., Sørensen, K. (1988). The GEEP Workshop: mesocosm exposures. Mar. Ecol. Prog. Ser. 46: 13-18

Bayne, B. L. (1965). Growth and delay of metamorphosis of the larvae of Mytilus edulis L. Ophelia 2: 1-47

Bayne, B. L. (1976). Marine mussels, their ecology and physiology. Cambridge University Press, Cambridge

Beaumont A. R., Budd, M. D. (1984). High mortality of the larvae of the common mussel at low concentrations of TBT Mar. Pollut. Bull. 15: 402-405

Bryne E. J., Calder, J. A. (1977). Effect of the water-soluble 
fractions of crude, refined and waste oils on the embryonic and larval stages of the quahog clam Mercenaria sp. Mar. Biol. 40: 225-231

Cormack, D. (1983). The use of aircraft for dispersant treatment of oil slicks at sea. Report of a joint UK Government Esso Petroleum Company Limited investigation. Marine Pollution Control Unit London, Department of Transport, Her Majesty's Stationary Office

Corner, E. D. S. (1978). Pollution studies with marine plankton. Part 1: Petroleum hydrocarbons and related compounds. Adv, mar. Biol. 15: 289-380

Dimick, R. E., Breese, W. P. (1965). Bay mussel embryo bioassay. Proc. 12th Pacific Northwest Industrial Waste Conf., College of Engineering, University of Washington

Dixon, D. R., Prosser, H. (1986). An investigation of the genotoxic effect of an organotin antifouling compound (bis tributyl tin oxide) on the chromosomes of Mytilus edulis Aquat. Toxicol. 8: 185-195
Goldberg, E. D., Bowen, V T., Farrington, J. W., Harvey, E., Martin, J H., Parker, P. L., Risebrough, R. W., Robertson, W., Schneider, E., Gamble, E. (1978). The Mussel Watch Environ. Conserv. 5: 1-25

Martin, M., Osborn, K., Billing, P., Glickstein, N. (1981). Toxicity of ten metals to Crassostrea gigas and Mytulus edulis embryos and Cancer magister larvae. Mar. Pollut. Bull. 12: $305-308$

Mitchell, D. G., Morgan, J. D., Vigers, G. A., Chapman, P. M. (1985). Acute toxicity of mine tailings to four marine species. Mar. Pollut. Bull. 16: 45-55

Stebbing, A. R. D., Akesson, B., Calabrese, A., Gentile, J. H., Jensen, A., Lloyd, R. (1980). The role of bioassays in marine pollution monitoring. Bioassay Panel Report. Rapp. P.-v. Réun. Cons. int. Explor. Mer 179: 322-332

Widdows, J., Johnson, D. (1988). Physiological energetics of Mytilus edulis: Scope for Growth. Mar. Ecol. Prog. Ser. 46: $113-121$ 